\title{
COVID-19 Konulu Medya ve İletişim Çalışmalarının Bibliyometrik Profili
}

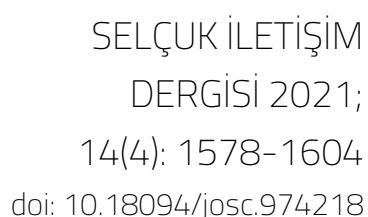

doi: $10.18094 /$ josc. 974218

\section{Hikmet Tosyalı}

\section{ÖZ}

Tüm dünyada uygulanan COVID-19 izolasyon tedbirleri kapsamında evde geçirilen süre arttıkça medya ve teknoloji kullanımı giderek artmıştır. Eğitim, sağlık, siyaset, kültür, sanat, alışveriş ve çalışma hayatı gibi pek çok konuda toplumsal dinamizm ve iletişim pratikleri derinden etkilenmiştir. Bireysel ve toplumsal yaşama ilişkin bu etkileri ve değişimi anlayabilmek için pek çok araştırma yapılmıştır. Bu araştırmalarda hangi konuların incelendiğinin ve genel özelliklerinin neler olduğunun belirlenmesi fikri, iletişim literatürüne ilişkin mevcut durumu ortaya koymak üzere bu araştırmaya dayanak oluşturmuştur. Bu çalışmada, tüm dünyayı derinden etkileyen COVID-19 hakkındaki medya ve iletişim çalışmalarının profilini keşfetmek amaçlanmıştır. Araştırmada, pandeminin yaklaşık ilk bir yılında Dergipark'ta yayımlanan 157 makale bibliyometrik veriler ve atıf analizi ile incelenmiştir. Makalelerin \%83,4'ü Türkçe yazılmıştır. Makaleler 95 fark Iı dergide yayımlanmış ve 236 araştırmacı makalelerde yazar olarak yer almıştır. Yazarların 67'si doktor öğretim üyesi, 33'ü araştırma görevlisi, 29'u doçent, 24'ü öğrenci, 23'ü öğretim görevlisi ve 19'u profesördür. Makalelerde 94 farklı üniversite adreslenmiştir. Ele alınan konuların başında sağlık iletişimi, pazarlama iletişimi, bilişim/yeni medya ve gazetecilik konuları gelmektedir. Araştırmaların \%64,3'ünde nitel metodoloji kullanılmıştır. İncelenen makalelerde 5.703 kaynağa atıf yapılmıştır. Bunların \%55,3'ü yabancı, \%44,7'si Türkçe kaynaklardır. En çok atıf yapılan kaynak türlerinin başında \%44,5 ile bilimsel dergiler yer almaktadır. Dergilere yapılan 2.536 atıf, 1.210 farklı dergiye dağılmaktadır. Selçuk iletişim, Computers in Human Behavior ve Journal of Business Research en çok atıf yapılan ilk üç dergidir. Elde edilen sonuçlar, bir taraftan araştırmacıların COVID-19 özelinde iletişimin hangi alt konularına odaklandıklarını ortaya koyarken diğer taraftan da iletişim literatürünün genel yapısına ve en etkili dergilerine ilişkin bir perspektif sunmaktadır.

Anahtar Sözcükler: Bibliyometri, Atıf Analizi, Medya, Iletişim Çalışmaları, COVID-19

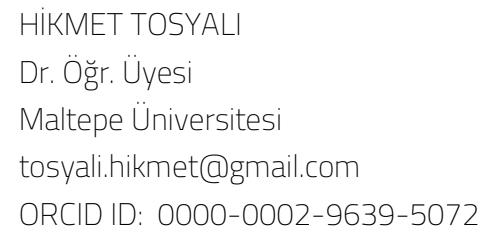




\section{Bibliometric Profile of Media and Communication Studies on COVID-}

19
JOURNAL OF SELÇUK

COMMUNICATION 2021;

14(4): 1578-1604

doi: $10.18094 /$ josc. 974218

$[\$$

SYELㄷIK

ILETISTM

\section{Hikmet Tosyalı}

\section{ABSTRACT}

As the time spent at home due to the COVID-19 isolation measures implemented worldwide increased, the use of media and technology has increased. Accordingly, social dynamism and communication practices have been affected in many subjects such as education, health, politics, culture, art, shopping and working life. Many studies were conducted to understand these effects and changes in individual and social life. Establishing topics examined in these studies and general characteristics of the studies have formed the basis of this research to reveal the current situation in the communication literature. Thus, it is aimed to explore the profile of media and communication studies on COVID-19 affecting the whole world. In the current study, 157 articles published in Dergipark in the first year of the pandemic were analyzed with bibliometric data and citation analysis. $83.4 \%$ of the articles were written in Turkish. The articles were published in 95 different journals, and 236 researchers took place as authors in the articles. Of the authors, 67 were assistant professors, 33 were research assistants, 29 were associate professors, 24 were students, 23 were lecturers and 19 were professors. In addition, 94 different universities were addressed in the articles. Health communication, marketing communication, informatics/new media and journalism were the main topics covered. Qualitative methodology was used in $64.3 \%$ of the studies. In the reviewed articles, 5,703 sources were cited. $55.3 \%$ of them were foreign sources, and $44.7 \%$ were Turkish sources. Scientific journals were the most cited source types with $44.5 \%$. Two thousand five hundred thirty-six citations to journals were distributed to 1,210 different journals. Journal of Selcuk Communication, Computers in Human Behavior and Journal of Business Research are the three most cited journals. The results reveal the subtopics of communication specific to COVID-19 and provide a perspective on the general structure of the communication literature and the most influential journals.

Keywords: Bibliometrics, Citation Analysis, Media, Communication Studies, COVID-19

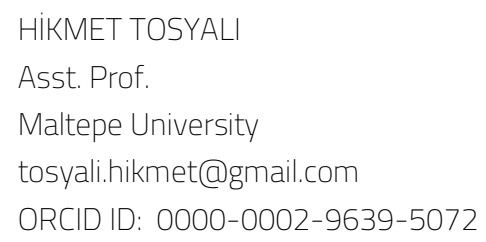




\section{Gíriş}

2019 Aralık ayının sonunda Çin'de ortaya çıkan yeni tip koronavirüs hastalığı (COVID-19) kısa sürede tüm dünyaya yayılımıştır (Sağlık Bakanlığı, 2020). Hükümetler, Dünya Sağlık Örgütü'nün 11 Mart 2020 tarihli küresel pandemi ilanıyla birlikte salgın yönetimi kapsamında aldıkları kararları uygulamaya başlamışlardır. Zorunlu izolasyon tedbirleri nedeniyle evlerine kapanan vatandaşlar için medya ve teknolojinin önemi bu süreçte giderek artmıştır. Özellikle sosyal medya, hastalıkla ilgili anlık bilgilere ve son dakika haberlerine ulaşmanın yanı sıra vatandaşların dünyaya açılan pencereleri haline gelmiştir.

Sosyal medya, sadece vatandaşlar için değil, pandemi yönetiminden sorumlu kişiler için de önemli rol üstlenmektedir. Hastalıkla ilgili riskler hakkında kamuoyu bilincinin yaratılması, halkın tedbirlere yönelik inançlarının pekiştirilmesi, yanıltıı bilgilerin engellenmesi gibi amaçlarla yürütülen iletişim çalışmalarında gerek geleneksel medya gerekse sosyal medya, kamu otoritesi ve sağlık uzmanlarınca yoğun olarak kullanılmaktadır (Tosyalı \& Tosyalı, 2021).

İolasyon sürecinde medya ve teknolojinin yoğun bir şekilde kullanılması, eğitim ve çalışma hayatı başta olmak üzere siyaset, sağık, alışveriş, kültür, sanat, eğlence ve sosyalleşme gibi pek çok konuda toplumsal dinamizmi ve iletişim pratiklerini derinden etkilemektedir. Medyanın ve iletişim teknolojilerinin bireysel ve toplumsal yaşama ilişkin bu etkilerini belirleyebilmek ve hayatın hemen her alanında gerçekleşmekte olan değişimi daha iyi anlayabilmek amacıyla çeşitli araştırmalar yürütülmektedir. Bu çalışmalarda hangi konuların ele alındığının ve genel özelliklerinin neler olduğunun belirlenmesi fikri ise iletişim literatürüne ilişkin mevcut durumu ortaya koymak üzere bu araştırmaya dayanak oluşturmuştur.

Yayınların yazar, konu, sayfa sayısı, atıf yapılan kaynaklar gibi belli özelliklerine göre niceliksel olarak analiz edilmesi ve böylece bilimsel iletişim sürecinin nasıl gerçekleştiğinin anlaşılması amacıyla pek çok disiplinde bibliyometriden yararlanılmaktadır (AI \& Tonta, 2004, s. 19). Bibliyometri, matematik ve istatistiksel yöntemlerin uygulanmasıyla başta kitap ve dergi olmak üzere bilimsel iletişim araçlarının genel kullanımını tespit etmek ve bunların tarihsel değişimlerini izlemek için kullanılmaktadır (Pritchard, 1969, s. 348).

Bibliyometrik veriler ve atıf analizi sayesinde hangi konular hakkında hangi kurumların ve yazarların çalışma yaptığı ve bu çalışmalarda hangi kaynakların kullanıldığı belirlenebilmektedir (Özel \& 
Kozak, 2012, s. 717). Bu bakımdan atıf analizi araştırmalarından elde edilen sonuçlar, bir konudaki en verimli araştırmacıların ve en sık kullanılan kaynakların belirlenmesinde, bilimsel araştırmaların değerlendirilmesinde, ilgili literatürün eskime hızının hesaplanmasında ve bu doğrultuda kütüphane koleksiyonlarının geliştirilmesinde kullanılmaktadır (Al \& Tonta, 2004, s. 21).

Atıfların dergilere göre dağııımını belirlemek için kullanılan bibliyometri yasalarından biri Bradford Yasasıdır. Buna göre herhangi bir konu veya disiplin hakkındaki makalelerin üçte biri küçük bir çekirdek dergi grubu tarafından yayımlanmaktadır. Makalelerin diğer üçte birlik kısmı ise öncekinden daha fazla sayıdaki ikinci bir dergi grubu tarafından yayımlanmaktadır. Çok daha fazla sayıdaki üçüncü bir dergi grubu ise makalelerin son üçte birlik kısmını yayımlamaktadır (Garfield, 1980, s. 477).

Pek çok alanda olduğu gibi iletişim alanının da genel yapısını ortaya koymaya yönelik bibliyometrik araştırmalar yapılmaktadır (Buhmann, Ihlen \& Aaen-Stockdale, 2019; Steensen \& Ahva, 2015; Ulu \& Akdağ, 2015). Bu araştırmaların bir kısmında bilimsel dergilerin etki değerlerinin de analiz edildiği anlaşılmaktadır (Demeter, 2018; Griffin, Bolkan \& Dahlbach, 2018; Vizoso, Pérez-Seijo, \& LópezGarcía, 2019). Türkiye'deki iletişim alanına yönelik bibliyometrik araştırmalarda ise incelenen makalelerin kaynakçalarında yer alan yayınlara yönelik atıf analizlerinin eksikliği göze çarpmaktadır. Ayrıca ekonomi (Handoko, 2021), finans (Rusydiana, 2021), yönetim (Öztürk \& Gök, 2020) ve sağlık (Doğan \& Doğan, 2020; Velayos-Ortega \& López-Carreño, 2020) gibi çeşitli alanlardaki COVID-19’u konu alan makalelerin bibliyometrik analizlerle incelendiği çalışmalar bulunmasına rağmen iletişim alanına yönelik böyle bir araştırmaya rastlanmamıştır. Dolayısıyla bu araştırmanın iletişim literatürüne ilişkin bir perspektif ortaya koyarak alana katkı sağlayacağı değerlendirilmektedir.

Sonuç olarak bu çalışmanın genel amacı, COVID-19 pandemisi hakkında iletişim alanında yayımlanan makalelerin bibliyometrik özelliklerinin belirlenmesi ve bu makalelerin kaynakçalarında yer alan atıfların bilimsel dergilere göre dağılımının tespit edilmesidir. Bu amaçla çalışmanın ilk bölümünde literatürde yer alan bibliyometrik araştırmalar derlenmiştir. Ardından Türkiye'de iletişim alanında yayımlanan COVID-19 konulu makalelerin bibliyometrik özellikleri ve atıf analizi sonuçları incelenmiştir. Makalelerin kaynakçalarında yer alan atıfların dergilere göre dağılımı Bradford Yasası doğrultusunda değerlendirilmiştir. 


\section{ÖNCEKI ÇALIŞMALAR}

Doğa bilimlerinde ortaya çıkan bibliyometrik yaklaşım (Garfield, 1955; Price, 1986), günümüzde sosyal bilimlerin pek çok alanında popüler bir analiz biçimi olarak kullanılmaktadır. Antropoloji (Demir, 2018), siyaset bilimi (Cansun \& Arık, 2019), sosyoloji (Koç, 2020), işletme (Fetscherin, Voss, \& Gugler, 2010), turizm (Özel \& Kozak, 2012) ve eğitim bilimleri (Doğan \& Tok, 2018) gibi pek çok disiplinde bibliyometriden yararlanılmaktadır.

Son yıllarda medya ve iletişim konularında da benzer çalışmaların yapıldığı görülmektedir. Habermas'ın teorilerinin halkla ilişkiler makalelerinde nasıl kullanıldığını belirlemek üzere Buhmann ve diğerleri (2019) tarafından yapılan araştırmada, 1980 ile 2016 yılları arasında yayımlanan ve Habermas'ın çalışmalarına atıf yapılan 263 makale incelenmiştir. Sonuçlar, Habermasçı teorilerin kullanımının özellikle son on yılda önemli ölçüde arttığını göstermektedir. İncelenen makalelerde teorilerden etkilenen üç ana araştırma kümesi tespit edilmişstir: Halkla ilişkiler ve kamusal alan, diyalojik paydaş iletişimi, halkla ilişkiler ve iletişim etiği.

Vanc ve Fitzpatrick (2016), iletişim araştırmacılarının 1990-2014 yılları arasındaki kamu diplomasisi yayınlarını incelemişlerdir. Araştırma sonuçlarına göre belirtilen yıllar arasında konuyla ilgili toplam 120 çalışma yayımlanmıştır. Bunların 102'si bilimsel dergilerde yayımlanan makale, 12'si kitap bölümü, 4'ü kitap ve 2'si monograftır. Iletişim araştırmacılarının kamu diplomasisi alanındaki çalışmalarının sayısı 2003'ten sonra artış göstermektedir. 1990-1997 arasında 4 çalışma yayımlanırken, 1998-2002 arasında çalışma bulunmamaktadır. En fazla çalışma, 20 makale ile 2012 yılında yayımlanmıştır. Konuyla ilgili en fazla makale yayımlayan dergiler ise Public Relations Review, Place Branding and Public Diplomacy, American Behavioral Scientist, Journal of Communication Management, Journal of Public Relations Research olarak tespit edilmiştir.

Tüketici-marka ilişkilerini konu alan bir araştırmada, Social Sciences Citation Index (SSCI) kapsamındaki dergilerde 1998 ile 2010 yılları arasında yayımlanan 392 makale incelenmiştir. Makalelerin, iletişim alanıyla ilgili dergilerin yanı sıra işletme, yönetim, psikoloji ve turizm gibi alanlardaki toplam 101 dergide yayımlandığı tespit edilmiş ve iletişim alanının disiplinlerarası yapısı ortaya konmuştur. Makale sayısı ve atıf analizi sonuçları, tüketici-marka ilişkileri konusunun köklerini pazarlama alanındaki dergilerin oluşturduğunu göstermektedir. Alanı domine eden en etkili dergiler ise Journal of 
Consumer Research, Advances in Consumer Research, Psychology \& Marketing, Journal of Business Research, Journal of Marketing ve Journal of Marketing Research olarak tespit edilmiştir. Makaleleri kaleme alan 685 yazarın görev yaptıkları üniversiteler incelendiğinde en etkili kurumlar Wisconsin Üniversitesi, Columbia Üniversitesi ve Boston College şeklinde sıralanmaktadır (Fetscherin \& Heinrich, 2015).

Kim, Avery ve Lariscy (2009), 11 farklı dergide yayımlanan 51 makaleyi analiz ederek kriz iletişimi literatürünü incelemişlerdir. Elde edilen sonuçlar, kuruluşların en sık kullandıkları kriz müdahale stratejilerinin güçlendirme, inkâr, düzeltici eylem, küçük düşürme ve suçu başkasına yükleme olduğunu ortaya koymaktadır. Kuruluşlar kriz anlarında bu stratejilerden en az ikisini aynı anda kullanmaktadır. Incelenen makalelerdeki değerlendirmelere göre en etkili kriz stratejisi özür, en az etkili strateji ise inkârdır. Makalelerde ele alınan kriz durumlarının çoğunluğu önlenebilir krizler ve kazalardan oluşmaktadır.

Bilimsel araştırmaların internet reklamcılığını nasıl şekillendirdiğini ortaya koymak üzere Kim ve McMillan (2008) tarafından yapılan çalışmada ise SSCI'da taranan reklamcılık dergilerinde 1994-2003 yılları arasında yayımlanan 113 makale ve bu makalelerde atıf yapılan 2.935 yayın analiz edilmiştir. Araştırma sonuçlarına göre ilk internet reklamcılığı makalesi 1996 yılında Journal of Advertising Research'de yayımlanmıştır. En çok atıf alan ilk üç dergi ise Journal of Advertising Research, Journal of Consumer Research ve Journal of Interactive Advertising olarak tespit edilmiştir. Sonuçlar, internet reklamcılığı konusunun şekillenmesinde Journal of Advertising Research dergisinin önemli rolünü ortaya koymaktadır.

Türkiye'de de medya ve iletişimi konu alan makalelere yönelik çeşitli çalışmaların yapıldığı görülmektedir. Yapılan bir araştırmada, TR Dizin veritabanında yer alan dergilerde 2003-2019 yılları arasında yayımlanan dijital pazarlama konulu 158 makale incelenmiştir. Sonuçlara göre en çok makalenin yayımlandığı ilk beş dergi: Akdeniz Üniversitesi Illetişim Fakültesi Dergisi, Bilişim Teknolojileri Online Dergisi, Erciyes Iletişim Dergisi, Uluslararası Sosyal Araştırmalar Dergisi ve Selçuk Iletişim Dergisi olarak tespit edilmiştir (Zeren \& Kaya, 2020).

Halkla ilişkiler alanında Türkiye'de yayımlanan 301 makalenin incelendiği başka bir araştırmada yayın sayılarına göre yapılan dergi sıralamasındaki ilk üç dergi şu şekildedir: İstanbul Üniversitesi Iletişim Fakültesi Dergisi, Selçuk Üniversitesi Iletişim Fakültesi Akademik Dergisi ve Marmara Illetişim Dergisi. Konu 
dağılımına göre en fazla makalenin dâhil olduğu ilk üç kategori ise kamu yönetimi, kurumsal iletişim ve internet-web siteleri olarak belirlenmiştir (Maden \& Okmeydan, 2017).

Başka bir çalışmada ise Selçuk Iletişim dergisinin bibliyometrik profili incelenmiştir. 1999-2013 yılları arasında yayımlanan 467 makalenin analiz edildiği çalışmanın sonuçlarına göre dergiye katkı sağlayan yazarların unvanlarına göre dağıımı şu şekildedir: Yardımcı Doçent \%37, Araştırma Görevlisi \%27, Doçent \%11, doktoralı araştırmacı \%9, Öğretim Görevlisi \%7, bağımsız araştırmacı \%6 ve Profesör \%3. Makale başına ortalama anahtar sözcük sayısı 3,98, başlıklarda geçen ortalama kelime sayısı 8, ortalama sayfa sayısı 12,21 ve ortalama kaynakça sayısı ise 27,40 olarak tespit edilmiştir. Makalelerin \%75,5'i tek yazar tarafından kaleme alınmıştır (Ulu \& Akdağ, 2015).

Iletişim alanında hazırlanan lisansüstü tezlere yönelik olarak da çeşitli çalışmalar yürütülmektedir (İnceoğlu, 2014; Okmeydan, 2020). Bu çalışmalardan birinde, 2006-2016 yılları arasında tamamlanan 895 doktora tezi incelenmiştir. Konu dağılımına göre en fazla çalışmanın Halkla İlişkiler ve Tanıtım/Reklamcılık anabilim dalında yapıldığı görülmektedir. Doktora tezlerinde öne çıkan konu başlıkları; medya çalışmaları, yeni iletişim teknolojileri, sinema çalışmaları, kurumsal iletişim ve halkla ilişkiler uygulamaları, pazarlama iletişimi ve siyasal iletişim şeklindedir. Araştırmalarda nitel yöntemler nicel yöntemlere göre daha fazla kullanılırken, karma yöntemlerin kullanıldığı az sayıda çalışma da bulunmaktadır (Davulcu \& Mazıcı, 2018).

Ayaz ve Ayaz (2017) tarafından yapılan araştırmada, sağlık iletişimi ve medyayı konu alan 234 lisansüstü tez analiz edilmiştir. Konuyla ilgili en çok çalışmanın yapıldığı anabilim dalları sırasıyla işletme, halk sağ lığı, gazetecilik, aile hekimliği, hemşirelik, halkla ilişkiler, sağlık yönetimi, iletişim, sosyoloji ve beslenme/diyetetik şeklindedir. Tezlerin \%82,1'i nicel, \%14,1'i nitel, \%3,4'ü ise karma yöntemle hazırlanmıştır.

Başka bir çalışmada ise gazete haberlerini konu alan 409 yüksek lisans tezi incelenmiştir. Elde edilen sonuçlar tezlerin gazetecilik, halkla ilişkiler ve tanıtım, radyo televizyon ve sinema, iletişim bilimleri, basın-yayın ve kültürel çalışmalar anabilim dallarında tamamlandığını ortaya koymaktadır. Çalışmaların \%75'i Gazi, Ankara, İstanbul, Marmara, Anadolu, Ege ve Selçuk Üniversitelerinde tamamlanmıştır. Tezlerde en çok güncel siyaset (siyasi aktörler ve olaylar), kimlik, şiddet ve toplumsal cinsiyet konuları ele alınırken, en az irdelenen konular ise çevre, kültür ve spor olarak belirlenmiştir. Veri 
analizinde en çok tercih edilen yöntemler içerik analizi (\%44) ve eleştirel söylem analizidir (\%29). Tezlerin \%8'inde ise her iki yöntem birlikte kullanıımıştır. Az sayıda çalışmada ise çerçeveleme, kaynak tarama, semiyoloji gibi yöntemler kullanılmıştır (Pelivan, 2019).

Pandeminin dünya gündemine girmesiyle birlikte başta sağlık olmak üzere çeşitli disiplinlerden araştırmacılar COVID-19 ile ilgili makaleleri bibliyometrik yöntemlerle incelemiş̧lerdir. Bu çalışmalardan birinde, Web of Science veritabanından erişilen COVID-19 hakkındaki 16.384 makale analiz edilmiş ve en verimli yazarlar, yayınlar, ülkeler, kurumlar ve disiplinler tespit edilmiştir. Araştırma sonuçlarına göre 19 farklı dildeki makalelerin büyük bölümünü $(\% 95,3)$ İngilizce yayınlar oluşturmaktadır. Türkçe ise 24 yayın sayısı ile onuncu sırada bulunmaktadır. Makaleler 157 farklı ülkedeki araştırmacılar tarafından yazılmıştır. En çok yayın yapan üç ülke Amerika Birleşik Devletleri, Çin ve İtalya olarak tespit edilmiştir. Araştırmacıların çalıştığı kurumlar sıralamasında ise ilk üçte Londra Üniversitesi, Harvard Üniversitesi ve Kaliforniya Üniversitesi bulunmaktadır. En çok makalenin yayımlandığı ilk on dergi, toplam makalelerin \%12'sini yayımlamıştır. BMJ 488 yayın sayısı ile en çok makalenin yayımlandığı dergi olarak tespit edilmiştir. Elde edilen sonuçlar, COVID-19 araştırmalarında ABD ve Çin arasındaki bilimsel işbirliğinin kilit rol oynadığını ve en güçlü ortak yazar bağlantısının ise New England Journal of Medicine ile JAMA dergileri arasında olduğunu ortaya koymaktadır. Makalelerin konu dağııımında ise ilk sırada genel ve dâhili tıp yer alırken, ikinci sırada halk, çevre ve iş sağlığı konuları, üçüncü sırada ise bulaşıcı hastalıklar konusu yer almaktadır (Al-Zaman, 2021).

Scopus veritabanından toplanan verilerin kullanıldığı bir araştırmada, işletme ve ekonomi alanlarındaki COVID-19 konulu 1.719 makale incelenmiştir. Araştırma sonuçlarına göre en çok makalenin yayımlandığı ilk üç dergi Gender Work and Organization, Finance Research Letters ve American Review of Public Administration, en üretken ülkeler ise Amerika Birleşik Devletleri, İngiltere ve Çin olarak tespit edilmiştir. Türkiye, 31 makale ile 111 ülkenin bulunduğu listenin 18. sırasında yer almaktadır. En üretken üniversiteler Pretoria Üniversitesi, Oxford Üniversitesi ve Merkez Florida Üniversitesi'dir. Makalelerde havacılık, turizm, bankacılık ve finans, tedarik zinciri, ekonomik büyüme, dijital ekonomi ve muhasebe konuları ele alınmıştır. Atıf analizi sonuçlarına göre ise en çok atıf yapılan ilk üç dergi Finance Research Letters, Tourism Geographies ve Journal of Business Research olarak tespit edilmiştir (Handoko, 2021). 
Başka bir araştırmada ise yönetim alanında COVID-19'u konu alan 440 makale analiz edilmiştir. Makalelere Web of Science veritabanı üzerinden erişilmiştir. En çok atıf alan makalelerin yayımlandıkları dergiler Journal of Nursing Management, Managing Sport and Leisure, Gender Work and Organization, Journal of Business Research, European Journal of Information Systems ve International Journal of Contemporary Hospitality Management olarak tespit edilmiştir. Sonuçlar, makalelerde ele alınan konuların liderlik, kriz yönetimi, sosyal medya, dayanıkııık, iyi oluş, girişimcilik, uzaktan çalışma, tüketici davranışları, sağlık sektörü ve kurumsal sosyal sorumluluk üzerine yoğunlaştığını ortaya koymaktadır (Öztürk \& Gök, 2020).

\section{YÖNTEM}

Bu araştırmada, COVID-19'un dünya gündemine girmesinden itibaren 2021 Mayıs ayına kadar geçen zaman diliminde yayımlanan medya ve iletişim çalışmaları incelenmiştir. Böylece, bireysel ve toplumsal hayatı derinden etkileyen COVID-19 pandemisi hakkında iletişim alanında yayımlanan makalelerin bibliyometrik özellikleri ve bu makalelerdeki atıflar incelenerek iletişim literatürüne ilişkin mevcut durumun ortaya konması amaçlanmıştır. Araştırmanın analiz birimi medya ve iletişim odaklı hakem denetimli yayımlanmış makalelerdir. Bir makalenin araştırma kapsamına dâhil edilmesi için belirlenen kriterler ise COVID-19 hakkında yazıımış ve medya/iletişim konularına odaklanmış olmasıdır.

Araştırmanın çalışma evreni Dergipark platformudur. Dergipark, Türkiye'de yayımlanan akademik hakemli dergiler için elektronik ortamda barındırma hizmeti sunmaktadır. Platform, açık erişimli dergilerin elektronik ortamda yönetilmesini sağlamaktadır ve oldukça yaygın düzeyde kullanıma sahiptir. 2020 verilerine göre platformdaki dergi sayısı 2.015, günlük ortalama kullanıcı sayısı ise 100 bin kişidir (Dergipark, 2020).

Araştırma kapsamına alınacak makaleleri saptamak amacıyla 24-25 Mayıs 2021 tarihlerinde "covid-19", "coronavirus", "koronavirüs", "pandemi" ve "salgın" kelimeleri kullanılarak Dergipark sistemine kayıtlı 5.010 makale taranmıştır. Arama sonuçları, makale türü alanından "araştırma makaleleri" seçeneği işaretlenerek önce 3.586'ya daha sonra konu alanından "sosyal" ve "ortak disiplinler" seçenekleriyle 1.163'e daraltılmıştır. Ulaşılan bu makalelerin tamamı incelenerek medya ve iletişim çalışmaları kapsamında olduğu değerlendirilen 157 hakem denetimli makale araştırmaya dâhil edilmişsir. Dolayısıyla bu araştırmada, söz konusu 157 makale aşağıdaki araştırma soruları kapsamında incelenmiştir. 
- COVID-19 hakkındaki medya ve iletişim makalelerinin sayısı zamanla artmakta mıdır?

- Makalelerin sayfa sayısına göre dağıımı nasıldır?

- Makalelerde en sık kullanılan anahtar sözcükler hangileridir?

- Makalelerin yayın diline göre dağııımı nasıldır?

- Makalelerde medya ve iletişim çalışmalarının en çok hangi konuları ele alınmıştır?

- Makalelerde hangi araştırma modelleri ve analiz teknikleri kullanılmıştır?

- En çok makale yayımlayan dergiler hangileridir?

- Makalelerin yazar sayısı ve unvanlara göre dağılımı nasıldır?

- Yazarların mensubu oldukları üniversiteler bakımından en çok makale yayımlayan kurumlar hangileridir?

- Makalelerde en sık atıf yapılan kaynakların özellikleri nelerdir?

- Makalelerde en sık atıf yapılan bilimsel dergiler hangileridir?

- Medya ve iletişim konularında yayın yapan çekirdek bir dergi grubu var mıdır?

Makaleler, araştırma sorularını yanıtlayacak şekilde yıl, sayfa sayısı, anahtar sözcük sayısı, yayın dili, konusu, araştırma modeli, veri toplama ve analiz teknikleri, yayımlandığı dergi, yazar sayısı, yazarların unvanları, yazarların mensubu (akademisyen/öğrenci/lisansüstü mezun) oldukları üniversiteler ve atıf yapılan kaynakların özellikleri bakımından sınıflandırılarak araştırmanın veritabanı oluşturulmuştur. Makalelerin konularına göre sınıflandırılmasında kullanılan kategoriler iletişim alanının anabilim ve bilim dalları temel alınarak belirlenmiştir. Her makale anahtar sözcükleri, kavramsal çerçevesi ve araştırma bölümü dikkate alınarak en çok ilgili olduğu tek bir konu altında değerlendirilmiştir. Araştırma modellerinin ve analiz tekniklerinin belirlenmesinde ise yazarların makalelerinde yaptıkları tanımlamalar esas alınmıştır.

Atıf analizinde, makalelerde atıf yapılan kaynaklar öncelikle türlerine (tez/bildiri/kitap/dergi/diğer) ve dillerine (Türkçe/yabancı) göre sınıflandırılmıştır. Dergilere yapılan atıflar, kaynakçalardaki yazım hataları düzeltilerek ve yıllar içinde adı değişen dergilerle ilgili kayıtlar birleştirilerek veritabanına eklenmiştir. Türkçe ve İngilizce olarak belirtilen aynı dergiler, Dergipark'ta kayıtı adı esas alınarak tekilleştirildikten sonra veritabanına eklenmiştir. Daha sonra iletişim alanında çekirdek bir dergi grubu olup olmadığını anlamak amacıyla atıfların dergilere dă̆ııımı Bradford Yasasına 
göre test edilmiştir. Bu aşamada Egghe ve Rousseau tarafından önerilen aşağıdaki hesaplama yöntemi (aktaran Tonta \& Al, 2008, s. 48) esas alınmıştır.

Öncelikle dergiler atıf sayılarına göre azalan şekilde sıralanmış ve elde edilen liste üç gruba ayrılmıştır. Gruplara ayırma işleminde, toplam atıf sayısı üçe bölünmüş ve her bir grubun eşit sayıda atıf içermesi sağlanmıştır. Sonraki adımda aşağıdaki formül kullanılarak Bradford Çarpanı (k) hesaplanmıştır. Formülde yer alan $(1,781)$, Euler katsayısını ve $y_{m}$ ise listenin birinci sırasındaki en çok atıf yapılan derginin atıf sayısını ifade etmektedir:

$$
k=\left(1,781 y_{m}\right)^{1 / 3}
$$

Son adımda ise aşağıdaki formüller kullanılarak Bradford Yasasına göre birinci $\left(r_{0}\right)$, ikinci $\left(r_{1}\right)$ ve üçüncü $\left(r_{2}\right)$ grupta kaçar derginin olması gerektiği hesaplanmıştır. Formülde yer alan $T_{\text {, listedeki toplam }}$ dergi sayısını ifade etmektedir:

$$
\begin{aligned}
& r_{0}=\left(T(k-1) /\left(k^{3}-1\right)\right) \\
& r_{1}=r_{0} k \\
& r_{2}=r_{0} k^{2}
\end{aligned}
$$

Bradford Yasasına göre birinci grupta yer alan dergiler $\left(r_{0}\right)$, en sık atıf yapılan çekirdek dergi grubunu tanımlamaktadır. İkinci gruptaki dergiler $\left(r_{7}\right)$, orta sıklıkta atıf yapılan dergileri ve üçüncü gruptakiler $\left(r_{2}\right)$ ise nadiren atıf yapılan dergileri tanımlamaktadır. Bu hesaplamalar, Türkiye dergileri ve yabancı dergiler için ayrı ayrı uygulanmıştır.

Makalelerin yukarıda açıklanan kategorilere göre kodlanması aşamasında güvenilirliği test etmek için bir öğretim üyesinden destek alınmıştır. Kodlayııılar arası güvenilirliği test etmek için makalelerin rastgele seçilen yüzde 10'luk kısmı için ön test uygulanmıştır. Bu işlem öncesinde diğer kodlayıcıya veritabanı ve kategoriler hakkında bilgi aktarıımıştır. Standart kategoriler (yıl, sayfa sayısı, anahtar sözcük sayısı, yayın dili, yayımlandığı dergi, yazar sayısı, yazarların unvanları, yazarların mensubu oldukları üniversiteler, atıf yapılan kaynakların özellikleri) için Holsti'nin kodlayıcılar arası güvenilirlik düzeyi 1,0 olarak tespit edilmiştir. Konu $(0,872)$, araştırma modeli $(0,985)$ ve analiz teknikleri $(0,760)$ için ise kodlayıcılar arasındaki ortalama güvenilirlik değerinin kabul edilen sınırlar (Landis \& Koch, 1977, s. 165) içinde gerçekleştiği tespit edilmiştir. 


\section{BULGULAR}

\section{Makalelerin yıl, sayfa sayısı, anahtar sözcük ve yayın diline göre dağılımı}

COVID-19'un dünya gündemine girmesiyle birlikte farklı disiplinlerden bilim insanlarının konu hakkında araştırma yapmaya başladıkları görülmektedir. Illetişim alanına yönelik COVID-19 makaleleri de Türkiye'de 2020 Nisan ayından itibaren yayımlanmaya başlamıştır. Bu tarihten itibaren 2020 yılının son üççeyreğinde yayımlanan makale sayısı 81'dir. 2021 yılının sadece ilk çeyreğinde yayımlanan makale sayısı ise $76^{\prime}$ dır.

Incelenen 157 makalenin toplam sayfa sayısı 2.982'dir. Dergilerin farklı sayfa tasarımları olması nedeniyle sayfa sayılarına göre daha anlamlı karşılaştırmaların yapılabilmesi amacıyla PDF formatında toplanan makaleler Microsoft Word programına aktarılarak kaynakçalar dâhil olmak üzere kelime sayıları da hesaplanmıştır. Buna göre makalelerin ortalama sayfa sayısı 19 (yaklaşık 6.750 kelime), en az sayfa sayısı 4 (yaklaşık 2.550 kelime) ve en fazla sayfa sayısı ise 46'dır (yaklaşık 14.950 kelime).

Makalelerde 435'i benzersiz olmak üzere toplam 737 anahtar sözcük kullanılmıştır. Makale başına 4,7 anahtar sözcük düşmektedir. En sık kullanılan ilk beş anahtar sözcük "covid-19", "sosyal medya", "pandemi", "koronavirüs" ve "twitter" şeklindedir. Anahtar sözcüklere ilişkin kelime bulutu Şekil 1'de gösterilmektedir.

Şekil 1 Anahtar Sözcüklere İlişkin Kelime Bulutu

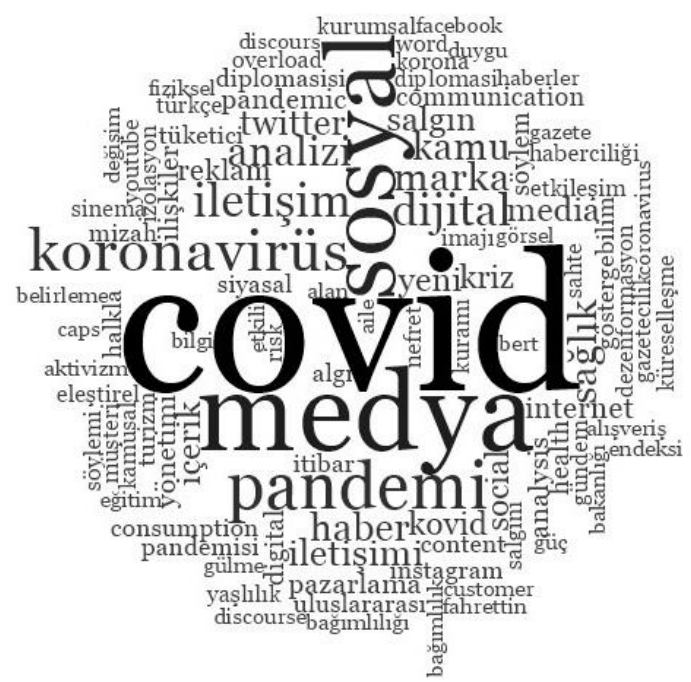


Araştırma kapsamında incelenen 157 makalenin 131'i Türkçe, 24'ü Ingilizce, 1'i Fransızca ve 1'i de Arapça dillerinde yazılmıştır. Türkçe makalelerin tamamında İngilizce özet, 36'sında ise genişletilmiş İngilizce özet bulunmaktadır. İngilizce yazılan 24 makalenin 17'sinde Türkçe özet, 4'ünde genişletilmiş Türkçe özet bulunmaktadır. Fransızca ve Arapça yazılan her iki makalede ise hem Türkçe hem de İngilizce özet yer almaktadır.

\section{Makalelerin konu, araştırma modeli, veri analizi teknikleri ve dergilere göre}

\section{dağılımı}

Tablo 1'de COVID-19 hakkındaki 157 makalenin konularına göre dağıımı sunulmaktadır. Tablo 1 'e göre makalelerde ele alınan konuların başında sağık iletişimi gelmektedir $(\% 20,4)$. Bu makalelerde sağıı çalışanlarının iletişim becerileri, bireylerin sağık davranışları ile sosyal medya arasındaki ilişki, kamuoyu bilinci yaratmada medyanın rolü, COVID-19 hakkında sosyal medyadaki bilgi kirliliği, kamu otoritelerinin ve sağlık uzmanlarının yürüttükleri risk iletişimi faaliyetleri gibi konular ele alınmıştır. Bu çalışmaların odağında çoğunlukla sosyal medya bulunmaktadır. 32 makalenin 14 'ünde ise Sağlık Bakanlığı ve Sağlık Bakanı başta olmak üzere Dünya Sağlık Örgütü, il sağlık müdürlükleri, hastaneler, sağlık uzmanları ve bilim kurulu üyeleri gibi kişi ve kurumların sosyal medya paylaşımları analiz edilmiştir. En çok incelenen ikinci konu pazarlama iletişimidir $(\% 19,1)$. Reklam, kamu spotu, marka ve tüketici davranışıyla ilgili araştırmaların yapıldığı makaleler bu kategoride yer almaktadır. Bilişim ve yeni medya, makalelerde en çok incelenen üçüncü konudur $(\% 18,5)$. Teknoloji, sosyal medya ve dijital uygulamalara yönelik kullanıcı araştırmaları, yeni medya ile bağımlılık/depresyon/stres/korku ilişkisi, dijital okuryazarlık, yeni medyada nefret söylemi, gözetim, mahremiyet ve dijital aktivizm hakkındaki makaleler bu kategoridedir. Dördüncü sırada ise habercilik pratikleri, okuyucu araştırmaları, ekonomi politik ve basın özgürlüğü konularının araştırıldığı gazetecilik makaleleri bulunmaktadır $(\% 17,8)$. Yukarıda sıralanan bu dört konu hakkında yazılan makaleler, toplam çalışmaların \%76'sını oluşturmaktadır. Bunları medya ve kültürel çalışmalar $(\% 5,1)$, tasarım $(\% 3,8)$, siyasal iletişim $(\% 3,8)$, kriz iletişimi $(\% 3,2)$, sinema/televizyon $(\% 2,6)$ ve diğer $(\% 5,7)$ konularda yayımlanan makaleler izlemektedir. Diğer kategorisinde ise imaj/itibar yönetimi, örgütsel iletişim, uluslararası halkla ilişkiler ve kamu diplomasisi konularında yazılan makaleler yer almaktadır. 
Tablo 1 Makalelerin Konularına Göre Dağılımı

\begin{tabular}{lrr}
\hline KONU & $\boldsymbol{n}$ & $\boldsymbol{\%}$ \\
\hline Sağlık Illetişimi & 32 & 20,4 \\
Pazarlama Illetişimi & 30 & 19,1 \\
Bilişim/Yeni Medya & 29 & 18,5 \\
Gazetecilik & 28 & 17,8 \\
Medya ve Kültürel Çalışmalar & 8 & 5,1 \\
Tasarım & 6 & 3,8 \\
Siyasal İletişim & 6 & 3,8 \\
Kriz İletişimi & 5 & 3,2 \\
Sinema/Televizyon & 4 & 2,6 \\
Diğer & 9 & 5,7 \\
\hline TOPLAM & $\mathbf{1 5 7}$ & $\mathbf{1 0 0 , 0}$ \\
\hline
\end{tabular}

Makalelerin araştırma modellerine göre dağılımı incelendiğinde, 101 araştırmada $(\% 64,3)$ nitel, 44 araştırmada $(\% 28)$ nicel ve 5 araştırmada $(\% 3,2)$ karma yöntemlerin kullanıldığı anlaşılmaktadır. 7 araştırmada $(\% 4,5)$ ise derleme yöntemi kullanılmıştır. Veri toplama yöntemi olarak 118 makalede doküman incelemesi, 26 makalede anket, 9 makalede görüşme, 5 makalede gözlem ve 2 makalede çevrimiçi etnografi yöntemleri kullanılmıştır. Makalelerin üçünde, birden fazla veri toplama yöntemi aynı anda kullanılmıştır.

Makalelerin veri analizi tekniklerine göre dağılımı incelendiğinde, nitel araştırmaların 48'inde içerik analizi, 22'sinde betimsel analiz, 19'unda eleştirel söylem analizi, 8'inde göstergebilimsel analiz, 4'ünde tematik analiz, 3'ünde görsel doküman analizi, 3'ünde örnek olay incelemesi ve 1'er makalede ise derlem dilbilim, fenomenoloji, iz sürme (tracer) ve özdüşünümsel analiz tekniklerinin kullanıldığı anlaşılmıştır. Nicel yöntemlerin kullanıldığı araştırmaların 40'ında betimleyici istatistikler (f; \%; $\mathrm{X}_{i} \mathrm{~S}$ ), 18'inde korelasyon, 11'inde t-testi, 11 'inde faktör analizi, 8'inde regresyon, 8'inde ANOVA, 4'ünde MannWhitney U, 3'ünde path analizi, 2'sinde Kruskal-Wallis ve 1'inde kümeleme analizinden yararlanılmıştır. Beş araştırmada ise metin madenciliği ve duygu analizi tekniklerinin kullanıldığı görülmüştür. Bazı makalelerde birden fazla veri analizi tekniği kullanıldığı için kodlanan tekniklerin sayısı makale sayısına göre daha fazladır.

Makalelerin yayımlandıkları dergilere ilişkin yapılan incelemede 95 farklı dergi tespit edilmiştir. En çok makale yayımlayan dergi 10 makale $(\% 6,4)$ ile OPUS Uluslararası Toplum Araştırmaları Dergisı'dir. İkinci sıradaki Inönü Üniversitesi Iletişim Fakültesi Elektronik Dergisi8 makale $(\% 5,1)$ yayımlamıştır. Gaziantep 
Üniversitesi Sosyal Bilimler Dergisi 7 makale (\%4,5), Avrasya Sosyal ve Ekonomi Araştırmaları Dergisi 6 makale $(\% 3,8)$ ve Turkish Online Journal of Design Art and Communication dergisi 5 makale $(\% 3,2)$ yayımlamıştır. Selçuk Iletişim ve Erciyes Illetişim dergileri ise 4'er makale yayımlamıştır. Bunların dışındaki 7 dergi 3'er makale, 11 dergi 2'şer makale ve 70 dergi 1'er makale yayımlamıştır.

\section{Yazarlara İlişkin Bulgular}

Makalelerin 91'i (\%58) tek yazarlı, 42'si (\%26,8) iki yazarlı, 18'i $(\% 11,5)$ üç yazarlı, 5'i $(\% 3,2)$ dört yazarlı ve 1'i ise $(\% 0,6)$ beş yazarlıdır. Makalelere 236 farklı yazar katkı sağlarken, 1 kişi 4 makalede, 3 kişi 3 makalede, 9 kişi 2 makalede ve 223 kişi ise 1'er makalede yazarlık yapmıştır.

Yazarların unvanlarına göre dağılımı incelendiğinde, 236 yazarın 67'sinin $(\% 28,3)$ üniversitelerin doktor öğretim üyesi kadrolarında görev yaptıkları anlaşılmıştır. Yazarların 33'ü (\%14) araştırma görevlisi, 29 'u $(\% 12,3)$ doçent ve 23 'ü $(\% 9,7)$ öğretim görevlisi kadrolarında çalışmaktadır. Araştırma görevlilerinin 8'i, öğretim görevlilerinin ise 9'u doktora derecesine sahiptir. Profesör kadrosunda görev yapanların sayısı 19'dur $(\% 8,1)$. Hekim ve doktoralı araştırmacı sayısı ise 10'dur $(\% 4,2)$. Yazarların 13'ü doktora, 8'i yüksek lisans ve 3'ü lisans düzeyinde olmak üzere \%10,2'si öğrencilerden oluşmaktadır. Yazarların 31'i $(\% 13,1)$ ise bağımsız araştırmacılardır (avukat, uzman, uzman yardımcısı, kamu ve özel sektör çalışanı vb.). Bu sonuçlara göre makalelere katkı sağlayan 236 yazarın 171'inin $(\% 72,5)$ üniversitelerde akademisyen olarak görev yaptıkları anlaşılmaktadır. Yazarların 142'si $(\% 60,2)$ ise doktoralı araştırmacılardan oluşmaktadır.

Yazarların hangi üniversite mensubu olduklarına bakıldığında, 94 farklı üniversite belirlenmiştir. Bu hesaplamada, bir üniversitede çalışan akademisyenlerin yanı sıra o kurumun öğrencileri ve lisansüstü mezunları de dikkate alınmıştır. Ortak yazarlı bir makalede tanımlanan her bir üniversite için o makale ayrı ayrı hesaplamaya alınmıştır. Bir üniversitenin aynı makalede birden fazla adreslenmesi durumunda ise ilgili üniversite için o makale yalnızca bir kere hesaplanmıştır. Bu kapsamda yapılan incelemede, iletişim alanında COVID-19'u konu alan en fazla makalenin Selçuk Üniversitesi (8 makale) ve daha sonra 7'şer makale ile İstanbul Üniversitesi, Kocaeli Üniversitesi ve Marmara Üniversitesi mensupları tarafından yazıldığı anlaşıımıştır. Bu kurumları 5'er makale ile Anadolu Üniversitesi, Ankara Hacı Bayram Veli Üniversitesi, Başkent Üniversitesi, Erciyes Üniversitesi ve Sağlık Bilimleri Üniversitesi izlemektedir. 


\section{Atıf Analizi}

Incelenen 157 makalede atıf yapılan kaynakların toplam sayısı 5.703'tür. Bunların 2.548'i (\%44,7) Türkçe, 3.155'i (\%55,3) yabancı dildedir. Tablo 2'de atıf yapılan kaynakların türlerine göre dağılımı gösterilmiştir. Tablo 2'ye göre atıfların $\% 44,5^{\prime} i$ bilimsel dergilerdeki makalelere, $\% 24,4^{\prime} u ̈$ kitaplara, $\% 2,8^{\prime} i$ konferans bildirilerine ve \%2,4'ü lisansüstü tezlere yapılmıştır. Diğer kategorisinde yer alan kanun, rapor, sosyal medya paylaşımı, film, röportaj, görsel ve internet sitesi gibi kaynaklara yapılan atıfların oranı ise $\% 25,9$ 'dur.

Tablo 2 Atıf Yapılan Kaynakların Türlerine Göre Dağııımı

\begin{tabular}{lrr}
\hline KAYNAK TÜRÜ & $\boldsymbol{n}$ & $\boldsymbol{\%}$ \\
\hline Dergi & 2.536 & 44,5 \\
Kitap & 1.389 & 24,4 \\
Bildiri & 159 & 2,8 \\
Tez & 139 & 2,4 \\
Diğer & 1.480 & 25,9 \\
\hline TOPLAM & $\mathbf{5 . 7 0 3}$ & $\mathbf{1 0 0 , 0}$ \\
\hline
\end{tabular}

Dergilere yapılan 2.536 atıf, 1.210 farklı dergiye dağılmaktadır. Tablo 3'te Türkiye dergilerinin ve yabancı dergilerin sayıları ile atıfların bu dergilere göre dağııımı sunulmaktadır. Tablo 3'e göre, atıf yapılan 1.210 derginin \%28,1'i Türkiye, \%71,9'u ise yabancı dergilerdir. Türkiye dergilerine yapılan atıflar, toplam atıfların \%32,5'ini oluşturmaktadır. Yabancı dergilere yapılan atıflar ise toplam atıfların \%67,5'ini oluşturmaktadır.

Tablo 3 Atıfların Dergi Türlerine Göre Dağılımı

\begin{tabular}{lrrrr}
\hline & \multicolumn{2}{c}{ DERGI SAYISI } & \multicolumn{2}{r}{ ATIF SAYISI } \\
\cline { 2 - 5 } Dergi Türü & $n$ & $\%$ & $n$ & $\%$ \\
\hline Türkiye dergileri & 340 & 28,1 & 824 & 32,5 \\
Yabancı dergiler & 870 & 71,9 & 1.712 & 67,5 \\
\hline TOPLAM & $\mathbf{1 . 2 1 0}$ & $\mathbf{1 0 0 , 0}$ & $\mathbf{2 . 5 3 6}$ & $\mathbf{1 0 0 , 0}$ \\
\hline
\end{tabular}

Atıfların dağılımının Bradford Yasasına uygunluğu, yöntem bölümünde açıklanan formüller kullanılarak Türkiye dergileri ve yabancı dergiler için ayrı ayrı test edilmiştir. Türkiye dergileri için yapılan test sonuçları Tablo 4'te verilmektedir. 
Tablo 4 Atıfların Türkiye Dergilerine Dağılımı

\begin{tabular}{rrrrrrrrr}
\hline & \multicolumn{3}{c}{$\begin{array}{c}\text { ARAŞTIRMA SONUÇLARINA GÖRE } \\
\text { ORTAYA ÇIKAN DAĞILIM }\end{array}$} & \multicolumn{2}{c}{$\begin{array}{c}\text { BRADFORD YASASINA GÖRE OLMASI } \\
\text { GEREKEN DAĞILIM }\end{array}$} \\
\cline { 2 - 11 } Grup & \multicolumn{2}{c}{ DERGI SAYISI } & \multicolumn{2}{c}{ ATIF SAYISI } & \multicolumn{2}{c}{ DERGI SAYISI } & \multicolumn{2}{c}{ ATIF SAYISI } \\
\cline { 2 - 10 } & $n$ & $\%$ & & $\%$ & $n$ & $\%$ & $n$ & $\%$ \\
\hline 1 & 19 & 5,6 & 272 & 33,0 & 15 & 4,4 & 274 & 33,2 \\
2 & 79 & 23,2 & 275 & 33,4 & 64 & 18,8 & 275 & 33,4 \\
3 & 242 & 71,2 & 277 & 33,6 & 261 & 76,8 & 275 & 33,4 \\
\hline TOPLAM & $\mathbf{3 4 0}$ & $\mathbf{1 0 0 , 0}$ & $\mathbf{8 2 4}$ & $\mathbf{1 0 0 , 0}$ & $\mathbf{3 4 0}$ & $\mathbf{1 0 0 , 0}$ & $\mathbf{8 2 4}$ & $\mathbf{1 0 0 , 0}$ \\
\hline
\end{tabular}

Tablo 4'e göre atıfların Türkiye dergilerine dağıımının Bradford Yasasına uyduğu söylenebilir. Bradford Yasasına göre birinci gruptaki (yani en sık atıf yapılan çekirdek) dergi sayısının 15 olması gerekmektedir. İkinci gruptaki orta sıklıkta atıf yapılan dergi sayısının 64, nadiren atıf yapılan üçüncü gruptaki dergi sayısının ise 261 olması gerekmektedir. Araştırma verilerine göre ortaya çıkan dağılımda birinci gruptaki çekirdek dergi sayısı 19, orta sıklıkta atıf yapılan dergi sayısı 79 ve nadiren atıf yapılan dergi sayısı 242 olarak tespit edilmiştir. İncelenen makalelerde en çok atıf yapııdığı tespit edilen 19 çekirdek derginin ilk 10'u Tablo 5'te gösterilmektedir.

Tablo 5 En Çok Atıf Yapılan Çekirdek Türkiye Dergileri

\begin{tabular}{rlr}
\hline & DERGi ADI & $\boldsymbol{n}$ \\
\hline 1 & Selçuk Iletişim & 39 \\
2 & Erciyes Iletişim Dergisi & 24 \\
3 & Akdeniz Üniversitesi Iletişim Fakültesi Dergisi & 20 \\
4 & Iletişim Kuram ve Araştırma Dergisi & 20 \\
5 & Gümüşhane Üniversitesi Iletişim Fakültesi Elektronik Dergisi & 18 \\
6 & Uluslararası Sosyal Araştırmalar Dergisi & 18 \\
7 & Connectist: Istanbul University Journal of Communication Sciences & 15 \\
8 & Gaziantep Üniversitesi Sosyal Bilimler Dergisi & 12 \\
9 & Kurgu & 12 \\
10 & Türkiye Iletişim Araştırmaları Dergisi & 12 \\
\hline
\end{tabular}

Tablo 5'in birinci sırasında 39 atıfla Selçuk Iletişim yer almaktadır. En sık atıf yapılan dergilerin sekizi iletişim fakülteleri tarafından yayımlanan alan dergileridir. İki dergi ise iletişimin yanı sıra sosyal bilimlerin diğer alanlarında da yayın yapan dergilerdir. Bu on dergi Türkiye dergilerinin yalnızca \%2,9'unu oluşturmaktadır. Öte yandan bu dergilere yapılan 190 atıf, 340 dergiye yapılan toplam 824 atıfın \%23,1 gibi önemli bir bölümünü karşılamaktadır. Atıfların yabancı dergilere dağıımının Bradford Yasasına uygun olup olmadığına ilişkin test sonuçları ise Tablo 6'da verilmiştir. 
Tablo 6 Atıfların Yabancı Dergilere Dağııımı

\begin{tabular}{rrrrrrrrr}
\hline & \multicolumn{2}{c}{$\begin{array}{c}\text { ARAŞTIRMA SONUÇLARINA GÖRE } \\
\text { ORTAYA ÇIKAN DAĞILIM }\end{array}$} & \multicolumn{3}{c}{$\begin{array}{c}\text { BRADFORD YASASINA GÖRE } \\
\text { OLMASI GEREKEN DAǦILIM }\end{array}$} \\
\cline { 2 - 10 } Grup & \multicolumn{2}{c}{ DERGI SAYISI } & \multicolumn{2}{c}{ ATIF SAYISI } & \multicolumn{2}{c}{ DERGI SAYISI } & \multicolumn{2}{c}{ ATIF SAYISI } \\
\cline { 2 - 10 } & $n$ & $\%$ & $n$ & $\%$ & $n$ & $\%$ & $n$ & $\%$ \\
\hline 1 & 59 & 6,8 & 571 & 33,4 & 42 & 4,8 & 571 & 33,4 \\
2 & 241 & 27,7 & 571 & 33,4 & 167 & 19,2 & 571 & 33,4 \\
3 & 570 & 65,5 & 570 & 33,2 & 661 & 76,0 & 570 & 33,2 \\
\hline TOPLAM & $\mathbf{8 7 0}$ & $\mathbf{1 0 0 , 0}$ & $\mathbf{1 . 7 1 2}$ & $\mathbf{1 0 0 , 0}$ & $\mathbf{8 7 0}$ & $\mathbf{1 0 0 , 0}$ & $\mathbf{1 . 7 1 2}$ & $\mathbf{1 0 0 , 0}$ \\
\hline
\end{tabular}

Tablo 6 incelendiğinde, Bradford Yasasına göre en sık atıf yapılan çekirdek dergi sayısının 42 olması gerektiği anlaşılmaktadır. Ikinci gruptaki orta sıklıkta atıf yapılan dergi sayısının 167, nadiren atıf yapılan üçüncü gruptaki dergi sayısının 661 olması gerekmektedir. Araştırma verilerine göre ortaya çıkan dağılımda ise birinci gruptaki çekirdek dergi sayısı 59, orta sıklıkta atıf yapılan dergi sayısı 241 ve nadiren atıf yapılan dergi sayısı 570 olarak tespit edilmiştir. Birinci ve ikinci gruptaki dergi sayıları öngörülenden yüksek, üçüncü gruptaki dergi sayısı ise daha düşük çıkmıştır. Ancak Bradford Yasasında tanımlandığı gibi atıfların üçte birlik $(\% 33,4)$ bölümünün az sayıdaki çekirdek dergiye, diğer üçte birlik bölümün öncekinden daha fazla sayıdaki ikinci dergi grubuna ve son üçte birlik bölümün ise çok daha fazla sayıdaki üçüncü dergi grubuna dağılması nedeniyle dergi sayılarının Bradford Yasasına uygun olduğu söylenebilir. En çok atıf yapıldığı tespit edilen 59 çekirdek derginin ilk 10'u Tablo 7'de sunulmaktadır.

Tablo 7 En Çok Atıf Yapılan Çekirdek Yabancı Dergiler

\begin{tabular}{rlr}
\hline DERGI ADI & $\boldsymbol{n}$ \\
\hline 1 & Computers in Human Behavior & 35 \\
2 & Journal of Business Research & 34 \\
3 & Public Relations Review & 27 \\
4 & Lancet & 21 \\
5 & Finance Research Letters & 20 \\
6 & Journal of Consumer Research & 16 \\
7 & Journal of Marketing & 16 \\
8 & Journal of Medical Internet Research & 16 \\
9 & PLOS ONE & 16 \\
10 & Communication Research & 13 \\
\hline
\end{tabular}

En çok atıf Computers in Human Behavior dergisine yapılmıştır (35 atıf). Bunu Journal of Business Research (34 atıf) ve Public Relations Review (27 atıf) dergileri takip etmektedir. Tablo 7'deki on dergi yabancı dergilerin \%1,2'sini oluşturmaktadır. Bu dergilere yapılan 214 atıf, 870 dergiye yapılan toplam 1.712 atıfın \%12,5'ini karşılamaktadır. 
Türkiye dergilerine ve yabancı dergilere yapılan atıflarda makale konularına göre bir farklılaşma olup olmadığı da incelenmiştir. Gazetecilik, kültürel çalışmalar, tasarım, siyasal iletişim ve sinema/televizyon konularında yazılan makalelerde yapılan atıflarda Türkiye dergileri öne çıkmaktadır. Örneğin gazetecilik makalelerinde en sık atıf yapılan ilk 10 derginin 8'i, siyasal iletişim makalelerinde ilk 10 derginin 6'sı ve sinema/televizyon makalelerinde ilk 10 derginin tamamı Türkiye'de yayımlanan dergilerdir. Yabancı dergilere yapılan atıfların ise sağık iletişimi, pazarlama iletişimi, bilişim/yeni medya ve kriz iletişimi makalelerinde yoğunlaştığı belirlenmiştir. Pazarlama iletişimi makalelerinde en sık atıf yapılan ilk 10 derginin tamamı yabancı dergilerdir. European Journal of Marketing, Tourism Management, Journal of Advertising, Journal of Marketing Research, Journal of Product \& Brand Management en sık atıf yapılan dergilerden bazılarıdır. Sağlık iletişimi, bilişim/yeni medya ve kriz iletişimi konularının ise üçünde de en sık atıf yapılan ilk 10 derginin 7'si yabancı dergilerdir. Tablo 7'dekilere ek olarak en sık atıf yapılan diğer bazı dergiler şu şekildedir: Journal of Health Communication, Health Communication, Journal of Communication, Communication Research, New Media \& Society, Journalism \& Mass Communication Quarterly, Digital Journalism, Social Media + Society, Public Opinion Quarterly.

\section{SONUÇ VE DEĞERLENDIRME}

Tüm dünyayı derinden etkileyen COVID-19 hakkındaki medya ve iletişim çalışmalarının profilini belirlemek ve bu çalışmalarda yapılan atıfların bilimsel dergilere dağııımını tespit etmek amacıyla yürütülen bu çalışmada, pandeminin yaklaşık ilk bir yılında Türkiye'de yayımlanan COVID-19 konulu iletişim makaleleri incelenmiştir. Araştırma sorularına yanıt aranarak bir taraftan araştırmacıların COVID19 özelinde iletişimin hangi alt konularına odaklandıkları belirlenmeye çalışılırken diğer taraftan da iletişim literatürünün genel yapısına ve en etkili dergilerine ilişkin bir perspektifin ortaya konmasına çalışılmıştır.

İncelenen makalelerde kullanılan anahtar sözcükler, araştırmaların odağında teknoloji, internet ve sosyal medyanın olduğunu göstermektedir. COVID-19'un bireysel ve toplumsal yaşamdaki etkileri zamanla derinleştikçe konu daha fazla araştırılmaya muhtaç hale gelmekte ve yayımlanan makale sayısı da buna paralel olarak artmaktadır. Bu süreçte sosyal bilimler alanındaki pek çok dergi özel sayılar yayımlayarak araştırma sonuçlarının bilim camiası ve toplumla paylaşılmasına imkân sağlamıştır. Her on makaleden sekizinin Türkçe yazıldığı anlaşılmaktadır. Bu durum küresel bir sorun olan pandemi hakkında 
yapılan araştırmaların yerelle sınırlı kalması riskini doğurmaktadır. Dergilerin \%27'si buna çözüm olarak Türkçe yazılan makalelerde İngilizce genişletilmiş özete yer verilmesini zorunlu tutmaktadır. Ancak Türkiye'de yapılan çalışmaların uluslararası görünürlügünnü artırmak üzere daha çok sayıda derginin bu uygulamayı başlatması gerektiği değerlendirilmektedir.

Makalelerde sağık iletişimi, pazarlama iletişimi, bilişim/yeni medya ve gazetecilik konuları ön plana çıkmaktadır. Başta Sağlık Bakanı olmak üzere çeşitli kişi ve kurumların sosyal medya paylaşımlarının incelendiği çok sayıda araştırma bulunmaktadır. Bazı çalışmalarda ise vatandaşların bu paylaşımlardan ve iletişim sürecinden nasıl etkilendiklerini ve kamuoyu bilinci yaratmada medyanın rolünü ortaya koymaya yönelik alan araştırmaları yapılmıştır. Pandemi dönemindeki gazetecilik ve habercilik pratikleri, markaların pandemi döneminde yürüttükleri iletişim çalışmaları, havayolu ve turizm başta olmak üzere çeşitli sektörlerin COVID-19'a ilişkin kriz iletişimi stratejileri, pandemi döneminde artan teknoloji kullanımına yönelik kullanıı araştırmaları, sosyal reklam ve kamu spotu araştırmaları makalelerde en çok ele alınan konulardan bazılarıdır.

İletişim araştırmalarında genellikle nitel yöntemler tercih edilmektedir (Davulcu \& Mazıcı, 2018; Pelivan, 2019). Bu araştırmada incelenen makalelerin de \%64,3'ünde nitel yöntem kullanılmıştır. İçerik analizi, eleştirel söylem analizi ve göstergebilim en çok kullanılan veri analizi teknikleridir. Nicel araştırmalarda ise veri analizinde en çok betimleyici istatistiklerden (frekans, yüzde, ortalama ve standart sapma) yararlanılmıştır. Sayısı az da olsa araştırmaların bir bölümünde ise sosyal ağ analizleri ve büyük veriyle ilgili metodolojilerin kullanıldığı görülmektedir. Bu çalışmalar, son yıllarda sosyal bilimlerin farklı alanlarında kullanımı giderek artan hesaplamalı/bilişimsel (computational) yöntemlerin iletişim alanında da giderek yaygınlaştığını ortaya koymaktadır. Mühendislik alanından araştırmacılarla ortak yürütülen bu çalışmalarda, metin madenciliği ve duygu analizi gibi yöntemler kullanılarak bireylerin sağlıkla ilgili konulardaki davranışları ve çevrimiçi sosyal ağlardaki COVID-19 gündemi araştırılmıştır.

Yazar profilleri incelendiğinde araştırmacılar arasındaki bu ortaklıkların yalnızca mühendislik alanıyla sınırlı olmadığı görülmektedir. Aslında bu beklenen bir durumdur. Çünkü yapılan araştırmalar sağlık iletişimi konusunun, iletişimin yanı sıra farklı anabilim dallarında da çalışılı̆ı̆ını göstermektedir (Ayaz \& Ayaz, 2017). Bu araştırmanın odağındaki COVID-19 makalelerinde de gerek iletişim araştırmacılarının kendi aralarında gerekse farklı disiplinlerden araştırmacılar arasında ortaklıkların 
kurulduğu görülmüştür. Zira makalelerin yarıya yakını çok yazarlıdır. Ayrıca makalelere katkı sağlayan 236 yazar, 94 üniversitenin iletişim, tıp, psikoloji, sosyoloji, hemşirelik, işletme, turizm gibi farklı alanlardaki akademik birimlerinde veya bağımsız araştırmacı olarak farklı kurumlarda görev yapmaktadır. Doktor öğretim üyesi ve araştırma görevlisi kadrolarında çalışan genç akademisyenlerin ve lisansüstü öğrencilerin literatüre katkı anlamında daha üretken oldukları anlaşılmaktadır. Bu durumun, akademik yükseltmeler ve lisansüstü mezuniyetler için gerekli olan yayın şartının sağlanmasıyla ilgili olabileceği değerlendirilmektedir. Yazarların unvanlarına göre verimlilik sıralaması, Ulu ve Akdağ'ın (2015) araştırmasıyla örtüşmektedir.

Incelenen makalelerde atıf yapılan kaynakların (dergi, kitap, bildiri, tez, diğer) \%55,3'ü yabancı dildeki eserlerden oluşmaktadır. Atıf yapılan kaynakların \%44,5'i bilimsel dergilerden, bunların da \%67,5'i yabancı dergilerden oluşmaktadır. Bilimsel dergiler, bilim dünyasındaki gelişmelerin ve güncel araştırmaların diğer bilim insanları ve toplumla paylaşıldığı en önemli kaynakların başında gelmektedir. Bu bakımdan belirtilen oranlar dikkate alındığında, araştırmacıların uluslararası ve güncel literatürü yakından takip ettikleri söylenebilir.

Atıf yapılan dergilerin Bradford Yasasına uygun oldukları anlaşılmış ve en sık atıf yapılan çekirdek dergiler tespit edilmiştir. Geçmişten günümüze iletişimin çeşitli konularında Türkiye'de en çok makale yayımlayan alan dergileri (Maden \& Okmeydan, 2017; Zeren \& Kaya, 2020), bu araştırmada tespit edilen çekirdek Türkiye dergilerini oluşturmaktadır. Ancak çekirdek dergilerin içinde sosyal bilimler alanında yayın yapan az sayıda dergi de bulunmaktadır. En çok atıf aldığı tespit edilen yabancı dergiler ise sıralamaları değişmekle birlikte literatürdeki pek çok araştırmayla örtüşmektedir (Fetscherin \& Heinrich, 2015; Kim \& McMillan, 2008; Vanc \& Fitzpatrick, 2016). Gazetecilik, kültürel çalışmalar, tasarım, siyasal iletişim ve sinema/televizyon konularında yazılan makalelerdeki atıflarda Türkiye dergileri öne çıkmaktadır. Pazarlama iletişimi, sağlık iletişimi, bilişim/yeni medya ve kriz iletişimi makalelerinde ise atıfların yabancı dergilerde yoğunlaştığı gözlenmiştir. Yabancı dergilerde iletişimin yanı sıra tıp, mühendislik, psikoloji, işletme ve turizm gibi farklı alanlardaki dergilere de fazla sayıda atıf yapılmıştır. Bu dergiler, COVID-19'u konu alan farklı alanlardaki atıf analizlerinden elde edilen sonuçlarla (AI-Zaman, 2021; Handoko, 2021; Öztürk \& Gök, 2020) benzerlik göstermektedir. Elde edilen bu sonuçlar, yazarların iletişim alanıyla kesişen konularda güncel literatürü takip ettiklerini, farklı alanlardaki araştırmacılarla ortaklıklar geliştirdiklerini ve diğer disiplinlerdeki araştırmacıların alana katkı sağladıklarını göstermesi 
bakımından önemlidir. Aynı zamanda bu sonuçların kütüphanelerde medya ve iletişim alanıyla ilgili çekirdek dergi koleksiyonlarının ve veritabanı aboneliklerinin oluşturulmasına da katkı sağlayacağı değerlendirilmektedir.

Bu araştırma, pandeminin ilk yılında Türkiye'de yayımlanan 157 makale ile sınırlıdır. Araştırmanın, pandeminin ilk yılından sonra yayımlanan makaleleri de içerecek şekilde ilerleyen zamanlarda tekrar edilmesi önerilmektedir. Bu sayede, gerek COVID-19 araştırmalarının niceliksel olarak değişimine gerekse konu dağılımlarındaki değişime ilişskin karşılaştırmaların yapılabileceği değerlendirilmektedir. Öte yandan yalnızca COVID-19 konulu makalelerin araştırma kapsamına alınması ise atıf analizinin önemli bir sınırııı̆ı̆ıı. İletişim alanına yönelik Türkiye'deki atıf analizi çalışmalarının eksikliği dikkate alındığında, daha geniş yıllara yayılarak tekrarlanacak çalışmalar sayesinde iletişim alanının genel yapısına iliş̧kin daha ayrıntıı bulgulara ulaşmak mümkündür. Atıfların dergilere dağııımı ve literatür eskimesi olguları, sonraki çalışmalarda iletişimin hem genel hem de alt alanları için ayrı ayrı incelenebilir. Bu sayede dergi abonelikleri konusunda daha geçerli politikalar geliştirilebilir.

\section{EXTENDED ABSTRACT}

As the time spent at home due to the COVID-19 isolation measures implemented worldwide increased, the use of media and technology has also increased. Accordingly, social dynamism and communication practices have been affected in many subjects such as education, health, politics, culture, art, shopping and working life. There have been many studies to understand these effects and changes in individual and social life. Establishing topics examined in these studies and general characteristics of the studies have formed the basis of this research to reveal the current situation in the communication literature. Thus, it is aimed to explore the profile of media and communication studies on COVID-19 affecting the whole world and the distribution of citations in these studies. The analysis unit of the research is peer-reviewed published articles focused on media and communication. As inclusion criteria for this research, papers written about COVID-19 and focused on media/communication issues were selected. In the study, 157 articles published in the first year of the pandemic were analyzed with bibliometric data and citation analysis.

The 157 reviewed articles were published in 95 different journals. The total number of pages of the articles is 2,982 , the average number of pages is 19 (approximately 6,750 words), the minimum 
number of pages is 4 (approximately 2,550 words), and the maximum number of pages is 46 (approximately 14,950 words). A total of 737 keywords, 435 of which were unique, were used in the articles. The keywords in the papers showed that the focus of studies was technology, the internet and social media. As the effects of COVID-19 on individual and social life deepen over time, the subject needs more research, and the number of published articles has increased in parallel. Many journals published special issues in this process, allowing the research results to be shared with the scientific community and society.

Health communication was the leading topic covered in the articles (20.4\%). In these articles, the communication skills of healthcare professionals, the relationship between individuals' health behaviors and social media, the role of the media in raising public awareness, information pollution on social media about COVID-19, risk communication activities carried out by public authorities, and healthcare professionals were discussed. The focus of these studies was mostly social media. The second most studied subject was marketing communication (19.1\%). Articles in which research on advertising, public service announcements, brands and consumer behavior were included in this category. Informatics/new media was the third most studied topic (18.5\%) in articles. In this category, articles on user research regarding technology, social media and digital applications, the relationship between new media and addiction/depression/stress/fear, digital literacy, hate speech in new media, surveillance, privacy and digital activism were included. Next, journalism articles on journalism practices, reader studies, political economy and press freedom were published $(17.8 \%)$. The articles written on these four subjects listed above constitute $76 \%$ of the total studies. These were followed by articles related to media and cultural studies $(5.1 \%)$, design $(3.8 \%)$, political communication $(3.8 \%)$, crisis communication $(3.2 \%)$, cinema/television (2.6\%) and others (5.7\%). Other categories included articles written on image/reputation management, organizational communication, international public relations and public diplomacy.

Qualitative methods were used in $64.3 \%$ of the articles, quantitative methods were used in $28 \%$, and mixed methods were used in 3.2\%. In 7 studies (4.5\%), review methodology was used. As data collection method, document review in 118 articles, questionnaire in 26 articles, interview in 9 articles, observation in 5 articles and online ethnography in 2 articles were used. Content analysis, critical discourse analysis and semiotics were the most used data analysis techniques. In quantitative studies, 
descriptive statistics (f, \%, X, S) were mostly used in data analysis. In some of the studies, social network analysis and methodologies related to big data were used. These studies reveal that computational methods, which have been increasingly used in different fields of social sciences in recent years, have become widespread in communication. In these studies carried out jointly with researchers from the field of engineering, methods such as text mining and sentiment analysis were used to investigate the behavior of individuals on health-related issues and the COVID-19 agenda in online social networks.

Having examined author profiles, it was seen that these partnerships between researchers are not limited to the field of engineering. Indeed, this is to be expected because health communication is a subject studied in different departments and communication. In the COVID-19 articles that are the focus of this research, it was observed that partnerships had been established between communication researchers and researchers from different disciplines since $42 \%$ of the articles had multiple authors. In addition, 236 authors who contributed to the articles work in the academic units of 94 universities in different fields such as communication, medicine, psychology, sociology, nursing, business, tourism or in different institutions as independent researchers.

The total number of references cited in the articles was 5,703. Of these, $2,548(44.7 \%)$ were in Turkish, and 3,155 (55.3\%) were in foreign languages. $44.5 \%$ of the citations were made to articles in scientific journals, $24.4 \%$ to books, $2.8 \%$ to conference proceedings and $2.4 \%$ to graduate theses. The rate of references made to other sources such as laws, reports, social media sharing, movies, interviews, visuals and websites was $25.9 \%$. Two thousand five hundred thirty-six citations to journals are distributed to 1,210 different journals. $32.5 \%$ of these were Turkish journals, and $67.5 \%$ were foreign journals. Scientific journals were one of the most important sources of science and recent research with other scientists and society. In this respect, considering the rates mentioned above, it can be said that the researchers closely follow the international and current literature.

It was understood that the cited journals were in compliance with the Bradford's Law, and the most frequently cited core journals were determined. Turkish journals have become prominent in the references section of articles on journalism, cultural studies, design, political communication and cinema/television. It has been observed that citations were clustered in foreign journals in marketing communication, health communication, informatics/new media and crisis communication articles. In 
addition to communication in foreign journals, a large number of references were made to journals in different fields such as medicine, engineering, psychology, business and tourism. These results are important as they showed that the authors follow the current literature on issues that intersect with communication, develop partnerships with researchers in different fields and contribute to the field by researchers from other disciplines. At the same time, it is considered that these results would contribute to the creation of core magazine collections and database subscriptions related to the field of media and communication in libraries. Considering the lack of citation analysis studies in communication in Turkey, it is possible to reach more detailed findings on the general structure of communication through the studies that could be repeated over the years. The distribution of citations to journals and growing literature can be examined separately for general and sub-fields of communication in future studies. In this way, more valid policies on journal subscriptions can be developed.

\section{KAYNAKÇA}

Al, U., \& Tonta, Y. (2004). Atıf analizi: Hacettepe Üniversitesi Kütüphanecilik Bölümü tezlerinde atıf yapılan kaynaklar. Bilgi Dünyası, 5(1), 19-47.

Al-Zaman, S. (2021). A bibliometric and co-occurrence analysis of COVID-19-related literature published between December 2019 and June 2020. Science Editing, 8(1), 57-63. doi:10.6087/kcse.230

Ayaz, F., \& Ayaz, H. (2017). Sağlık iletişimi ve medyayı konu alan lisansüstü tezlere yönelik bir analiz. Atatürk Iletişim Dergisi, 14, 147-172.

Buhmann, A., Ihlen, O., \& Aaen-Stockdale, C. (2019). Connecting the dots: A bibliometric review of Habermasian theory in public relations research. Journal of Communication Management, 23(4), 444-467. doi:10.1108/JCOM-12-2018-0127

Cansun, Ş., \& Arık, E. (2019). Türkiye adresli siyaset bilimi yayınlarının bibliyometrik analizi. Ankara Üniversitesi SBF Dergisi, 74(3), 853-874. doi:10.33630/ausbf.536774

Davulcu, E., \& Mazıcı, E. T. (2018). İletişim araştırmalarında 2006-2016 yılları arasında yapılan doktora tezlerine ilişkin bir durum değerlendirmesi. Karadeniz Teknik Üniversitesi Illetişim Araştırmaları Dergisi, 8(1), 55-73.

Demeter, M. (2018). Changing center and stagnant periphery in communication and media studies: National diversity of major international journals in the field of communication from 2013 to 2017. International Journal of Communication, 12, 2893-2921.

Demir, E. (2018). Antropoloji alanındaki yayınların bibliyometrik analizi. Hitit Üniversitesi Sosyal Bilimler Enstitüsü Dergisi, 11(2), 1511-1528. doi:10.17218/hititsosbil.458588

Dergipark. (2020). Hakkında. https://dergipark.org.tr/tr/pub/page/about adresinden alındı 
Doğan, G., \& Doğan, G. (2020). Statistical analysis of COVID-19 publications in the fields of pediatrics. Kırıkkale Üniversitesi Tıp Fakültesi Dergisi, 22(2), 254-262. doi:10.24938/kutfd.769806

Doğan, H., \& Tok, T. N. (2018). Türkiye'de eğitim bilimleri alanında yayınlanan makalelerin incelenmesi: Eğitim ve Bilim Dergisi örneği. Current Research in Education, 4(2), 94-109.

Fetscherin, M., \& Heinrich, D. (2015). Consumer brand relationships research: A bibliometric citation meta-analysis. Journal of Business Research, 68(2), 380-390. doi:10.1016/j.jbusres.2014.06.010

Fetscherin, M., Voss, H., \& Gugler, P. (2010). 30 Years of foreign direct investment to China: An interdisciplinary literature review. International Business Review, 19(3), 235-246. doi:10.1016/j.ibusrev.2009.12.002

Garfield, E. (1955). Citation indexes for science: A new dimension in documentation through association of ideas. Science, 108-111. doi:10.1126/science.122.3159.108

Garfield, E. (1980). Bradford's law and related statistical patterns. Essays of an Information Scientist, 4, 476-483. http://garfield.library.upenn.edu/essays/v4p476y1979-80.pdf adresinden alındı

Griffin, D. J., Bolkan, S., \& Dahlbach, B. J. (2018). Scholarly productivity in communication studies: Fiveyear review 2012-2016. Communication Education, 67(1), 88-101. doi:10.1080/03634523.2017.1385820

Handoko, L. H. (2021). COVID-19 research trends in the fields of economics and business in the Scopus database in November 2020. Science Editing, 8(1), 64-71. doi:10.6087/kcse.231

İnceoğlu, Ç. (2014). Türkiye'de sinemayı konu alan doktora tezleri üzerine bibliyometrik bir çözümleme. Galatasaray Üniversitesi Illetişim Dergisi, 21, 31-50. doi:10.16878/gsuilet.96674

Kim, J., \& McMillan, S. J. (2008). Evaluation of internet advertising research: A bibliometric analysis of citations from key sources. Journal of Advertising, 37(1), 99-112. doi:10.2753/JOA00913367370108

Kim, S., Avery, E. J., \& Lariscy, R. W. (2009). Are crisis communicators practicing what we preach?: An evaluation of crisis response strategy analyzed in public relations research from 1991 to 2009. Public Relations Review, 35(4), 446-448. doi:10.1016/j.pubrev.2009.08.002

Koç, O. (2020). Web of Science üzerinde indekslenen kadına yönelik şiddet araştırmalarına bibliyometrik bir bakış. istanbul Üniversitesi Kadın Araştırmaları Dergisi, 21, 19-35. doi:10.26650/iukad.2020.22.002

Landis, J. R., \& Koch, G. G. (1977). The measurement of observer agreement for categorical data. Biometrics, 33(1), 159-174. doi:10.2307/2529310

Maden, D., \& Okmeydan, S. B. (2017). Türkiye'de Halkla Illişkiler akademisyenleri ne çalışıyor? "Halkla İlişkiler" makalelerine yönelik bir inceleme. Erciyes Iletişim Dergisi, 5(2), 102-126. doi:10.17680/erciyesakademia.315376

Okmeydan, S. B. (2020). Kültürlerarası iletişim alanındaki eğilimler: 'Kültürlerarası Illetişim' başlıklı lisansüstü tezlerin bibliyometrik analizi. TRT Akademi, 5(10), 578-611.

Özel, Ç. H., \& Kozak, N. (2012). Turizm Pazarlaması Alanının Bibliyometrik Profili (2000-2010) ve Bir Atıf Analizi Çalışması. Türk Kütüphaneciliği, 26(4), 715-733. 
Öztürk, M., \& Gök, S. G. (2020). COVID-19 döneminde yönetim yazındaki araştırma trendlerinin bibliyometrik analiz yöntemi ile incelenmesi. Kapadokya Akademik Bakış, 4(2), 73-89.

Pelivan, M. (2019). Gazete haberlerini konu alan yüksek lisans tezlerine dair bibliyometrik bir analiz. Anadolu Üniversitesi Sosyal Bilimler Dergisi, 19(4), 119-148. doi:10.18037/ausbd.668631

Price, D. (1986). Little science, big science ... and beyond. New York: Columbia University Press.

Pritchard, A. (1969). Statistical bibliography or bibliometrics? Journal of Documentation, 25(4), 348-349.

Rusydiana, A. S. (2021). Bibliometric analysis of journals, authors, and topics related to COVID-19 and Islamic finance listed in the Dimensions database by Biblioshiny. Science Editing, 8(1), 72-78. doi: $10.6087 /$ kcse. 232

Sağlık Bakanlığı. (2020). COVID-19 Nedir? https://covid19.saglik.gov.tr adresinden alındı

Steensen, S., \& Ahva, L. (2015). Theories of Journalism in a Digital age. Digital Journalism, 3(1), 1-18. doi:10.1080/21670811.2014.927984

Tonta, Y., \& Al, U. (2008). Türkçe makalelerin dergilere dağılımı ve Bradford Yasası. Bilgi Dünyası, 9(1), 41 66.

Tosyalı, H., \& Tosyalı, F. (2021). Risk communication and social media: COVID-19 pandemic planning and response in Turkey. G. Sarı (Dü.) içinde, Handbook of Research on Representing Health and Medicine in Modern Media (s. 150-171). Hershey PA: IGI Global.

Ulu, S., \& Akdağ, M. (2015). Yayınlanan hakem denetimli makalelerin bibliyometrik profili: Selçuk iletişim Dergisi örneği. Selçuk Illetişim, 9(1), 5-21. doi:10.18094/si.04052

Vanc, A. M., \& Fitzpatrick, K. R. (2016). Scope and status of public diplomacy research by public relations scholars, 1990-2014. Public Relations Review, 42(3), 432-440. doi:10.1016/j.pubrev.2015.07.012

Velayos-Ortega, G., \& López-Carreño, R. (2020). Most cited journals in coronavirus patents according to Lens.org. Profesional de la Información, 29(5). doi:10.3145/epi.2020.sep.19

Vizoso, Á., Pérez-Seijo, S., \& López-García, X. (2019). Ten years of research in the highest ranked communication journals. Trends and subjects in JCR and SJR's highest impact publications. adComunica, 18, 245-270. doi:10.6035/2174-0992.2019.18.12

Zeren, D., \& Kaya, N. (2020). Dijital Pazarlama: Ulusal Yazının Bibliyometrik Analizi. Çağ Üniversitesi Sosyal Bilimler Dergisi, 17(1), 35-52. 